\title{
理想タングステン織條の* 眞空中に於ける燒斷壽命と動程
}

正會員山内二郎

(避信省電氣陚驗所)

真空タングステン電球の壽命について R. Becker ${ }^{(1)}$ 氏は，瀻條にくびれがあるためその部分

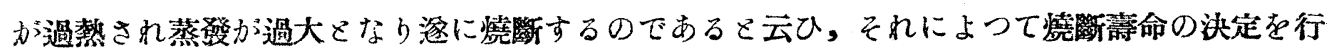
つて差支ないことを提案した。瀻條にくびれがなくても表面の輻射能のちがひ，結晶のための

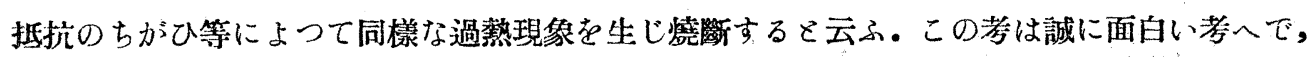
F. Koref 及 H. C. Plaut ${ }^{(2)}$ 兩氏は Becker の論を更にコイル繊條電球に押し擴め，ガスが入 つてるる場合でも同じ樣に，くびれの他にコイルの步みが大きな原因となることを示してる ๖.

L. Prásnik ${ }^{(3)}$ 氏は Becker の論を數式を以て說明し，更に過熱部分からの熱の傳導を考へた 場合を諭じてるる.

實際の電球では，纎條の品質，兩端や吊子に於ける冷却等が影響して，勢ひ統計的な議諭の みになつて了つて，事の真相を知り得ない恐れが多分にある。幸にして理想タンダステンの場 合にはそのやうな煩ひもなくまた高溫度に於ける諸特性がよく調べられてるるから，理想タ ングステンについて諭じておけば，その結諭を實際の電球の場合に援用して，車䡚を明かにす

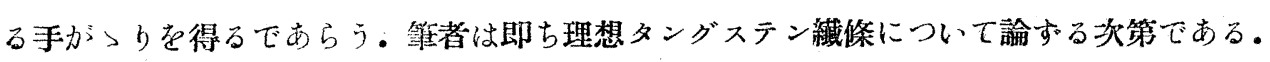

\section{1. 假定}

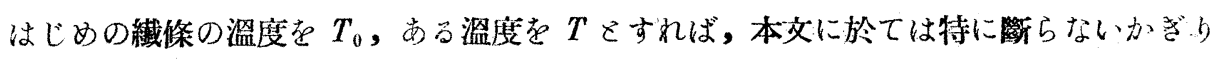

$$
\tau=\frac{T}{T_{0}}
$$

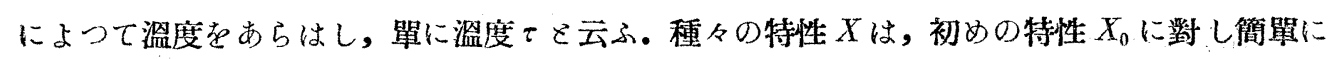

$$
\frac{X}{X_{0}}=\tau^{n_{X}}
$$

としてあらはされるものと假定した。

くびれの部分は短くて，全體の特性には影䇾しないものを假定する。

* Burn-out Life and Performance of Ideal Tungsten Filament in Vacuum, by Dr. Z. Yamauti, Member (Denki Sikenzyo)

(1)R. Becker : Z. f. techn. Phys. (6) S. 309-313, 1925.

(2) F. Koref und H. C. Plaut : Z. f. techn. Phys. (11)S. 515-522, 1930.

(3) L. Prúsnik : Z. f. Phys. (72) S. $86-94$, 1931; ibid. (75) S. 417-420, 1932; ibid (77) S. 127132, 1932. 
纎條は理想タングステンの直線臓條で，真空中に點火し，導入線や吊子等による冷却はない。 まのと假定する。

\section{2. 蒸㻐の基本式}

タングステンの密度を $w$, 蒸發率を $M$, 直徑 $D$, 長さ $l$, 時間を $t$ をする

$$
M d t=-\frac{\pi}{2} D d D l w
$$

である。

くびれのない繊條の始めの直徑を $D_{0}$ とし，

$$
\begin{aligned}
t^{\prime} & =\frac{t}{D_{0}} \\
\delta & =\frac{D}{D_{0}}
\end{aligned}
$$

とし，固有蒸發率を $\boldsymbol{M}^{\prime}$ とすれば，上式は

$$
d t^{\prime}=-\frac{\pi}{2} \frac{w}{M^{\prime}} d \delta
$$

そなる。これが即ち蒸發の基本式であつて，この式から明かなことは，動程，关命を論するに

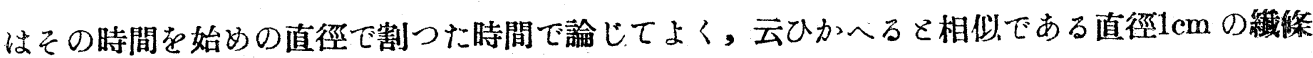

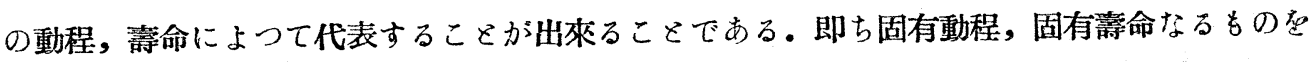
導入して猃することが出來，甚だ便利である。

\section{3. くびれた部分の變化}

\section{1 直徑及溫度の關係}

加熱電流はくびれてわない部分によつて決定され，それかくびれた部分をも通るためににく びれた部分が過熱される。

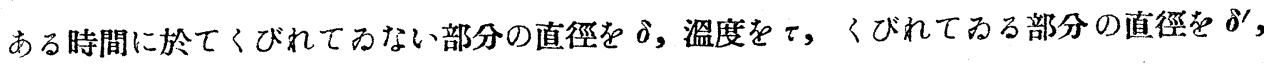
溫度をてとすれば，雨部分を通る電流の等しいことから

$$
\tau^{\frac{n_{W}-n_{R}}{2}} \frac{3}{\delta^{2}}=\tau^{\prime} \frac{n_{W}-n_{R}}{2} \frac{3}{\delta^{\prime}}
$$

の關係がある。或は

$$
\begin{gathered}
\tau_{W}^{\frac{n_{W}-n_{R}}{3}}{ }_{\delta=\tau^{\prime}}^{\frac{n_{W}-n_{R}}{3}} \delta^{\prime} \\
\tau^{\prime}=\tau\left(\frac{\delta}{\delta^{\prime}}\right)^{\frac{3}{n_{W}-n_{R}}} \ldots
\end{gathered}
$$

である。

(2.1) 式によつて

$$
\frac{d \delta}{\tau^{n_{M}}}=\frac{d \delta^{\prime}}{\tau^{\prime n_{M}}}
$$


であるから，(3.1b) 式を入れて

$$
d \delta . \delta^{\frac{3 n_{M}}{n_{W}-n_{R}}}=d \delta^{\prime} . \delta^{\frac{3 n_{M}}{n_{W}-n_{R}}}
$$

そなる・今

$$
m=\frac{3 n_{M}}{n_{W}-n_{R}}+1
$$

モょけば，(3，3)・式は

$d \delta . d^{m-1}=d \delta^{\prime} . \delta^{\prime m-1}$

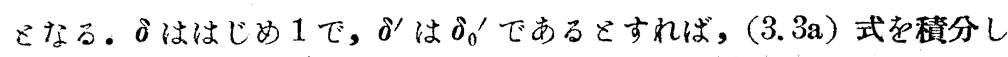

$$
\frac{1}{m}\left(1-\delta^{m}\right)=\frac{1}{m}\left(\grave{\delta}_{0}^{\prime m}-\delta^{\prime m}\right)
$$

或は $1-\delta^{m}=\delta_{0}{ }^{\prime m}-\delta^{\prime m}$

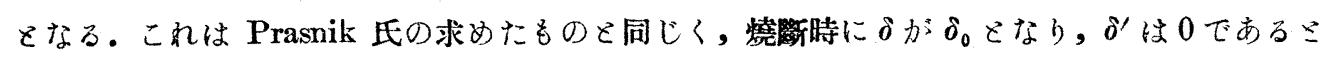
すれば (3.5) 式は

$$
1-\delta_{0}{ }^{m}=\delta_{0}{ }^{m} \text {. }
$$

こなり, Koref 及 Plaut 兩氏の示した通りとなる。

(3.5)式はくびれた部分の直徑とくびれてるない部分の直徑との關係を與へてるるから，こ れから $\delta$ に對する $\delta^{\prime}$ を求め，前章の動程によつて各時間に於けるくびれた部分の $\delta^{\prime}$ が分明 しまた (3.1b) 式によつて溫度で俅められることとなる。

(3.6) 式によつて次の結諭を得。

特性の何れを一定にしても, 燒斷時に於ける織條の直徑ははじめのくびれの直徑によつて䇥 つたある値となる。その關係はくびれてるない部分のはじめの溫度の函數である。

同樣の結論が (3. 5) 式及 (3.1b) 式から头のやうに下せる。

動程に於けるくびれてるない部分とくびれてるる部分との直徑の關係ははじめの溫度及くび れの直徑によつて定まる。また溫度の關係も同じであつて，共に一定とする特性の如何に沙 係しない。

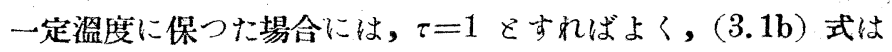

$$
\tau^{\prime}=\left(\frac{\delta}{\delta^{\prime}}\right)^{\frac{3}{n_{W}-n_{R}}} .
$$

となり，(3.2) 式は

$$
d \delta=\frac{d \delta^{\prime}}{\tau^{\prime} n^{M}}
$$

そなるから，(3．3) 式以下全く同じ・故に上に述べけ結論はこの場合にも當てはまる。 


\section{2 指數 $\mathrm{m}$ の值}

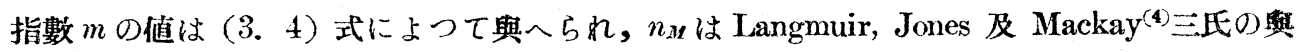
へた固有烝發率の式

$$
\log _{10} M^{\prime}=9.725-\frac{41940}{T}-0.3650 \log _{10} T-0.0001639 T
$$

加求甘

$$
n_{M}=\frac{96570}{T}-0.3650-0.0003774 T \text {. }
$$

であり, $n_{W}$ 及 $n_{R}$ は筆者(汭が管て求めておいた通り

$$
\begin{aligned}
& n_{W}=3.563+\frac{2721}{T} \\
& n_{R}=1.261-\frac{158}{T} .
\end{aligned}
$$

であるから

$$
\theta=\frac{T}{2500}-1
$$

とおいてて計算すると

$$
m=33.41 \frac{1-0.0386 \theta-0.0025 \theta^{2}}{1+\frac{2}{3} \theta}
$$

となる。これによつて求めた

に示す通りである・(第1圖)

第1表 $m$ の 値

\begin{tabular}{c|c||c|c}
\hline$T\left({ }^{\circ} \mathrm{K}\right)$ & $m$ の 值 & $T\left({ }^{\circ} \mathrm{K}\right)$ & $m$ の 值 \\
\hline 2300 & 35.40 & 2600 & 32.49 \\
2400 & 34.38 & 2700 & 31.62 \\
2500 & 33.41 & 2800 & 30.79
\end{tabular}

Koref 及 Plaut ${ }^{(2)}$ 兩氏は買空電球に路して $m=35$ ，ガス入電球 $220 \mathrm{~V} / 40 \mathrm{~W} に$ に $m=45$, $110 \mathrm{~V} / 75 \mathrm{~W}$ には $m=40$ 学與へてるる。

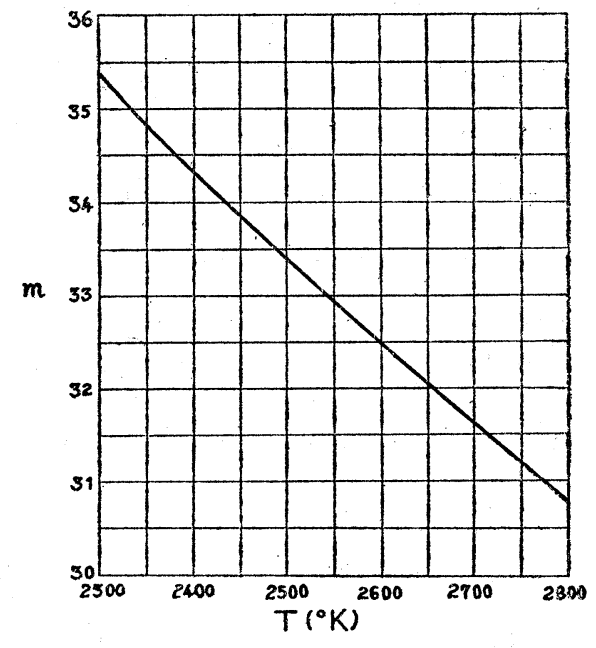

第 1 圆

\section{3 数 字 例}

（a）くびれの值徑と燒斷時の直徑

くびれの直徑 $\delta_{0}^{\prime}$ に對し, 種々の初溫度のときの燒断時の直徑 $\delta_{0}$ の值の數字例を示せば,

(4)Phys. Rev., (30) 1927, p. 201. (5)山丙及西川：照學譕 (16) P. 91，昭和 7 年 
(3.6) 式により第 2 表の如し.

第 2 表 $\cdots \delta_{0} \quad$ の 値

\begin{tabular}{c|c|c|c}
\hline$T^{0} \mathrm{~K}$ & 2300 & 2400 & 2500 \\
\hline 0.99 & 0.9665 & 0.9648 & 0.9632 \\
0.98 & 0.9812 & 0.9798 & 0.9789 \\
0.97 & 0.9883 & 0.9875 & 0.9867
\end{tabular}

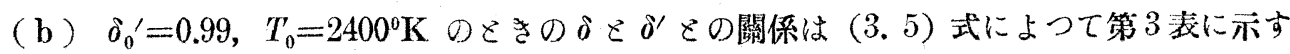
やうになる，即ち $\delta^{\prime}$ の變化は割合に緩漫で尋命の終りに近づいて急激に隇少してるることが わかる。

第 3 表 $\quad \delta_{0}^{\prime}=0.99, \quad T_{0}=2400^{\circ} \mathrm{K}$

\begin{tabular}{|c|c|c|c|c|c|c|c|}
\hline$\delta$ & $\delta^{\prime}$ & $\tau^{\prime}$ & $T^{\prime}\left({ }^{0} \mathrm{~K}\right)$ & $\delta$ & $\delta^{\prime}$ & $\tau^{\prime}$ & $T^{\prime}\left({ }^{0} \mathrm{~K}\right)$ \\
\hline 1.00 & 0.99 & 1.0086 & 2421 & 0.975 & 0.9417 & 1.0302 & 2472 \\
\hline 0.995 & 0.9823 & 1.0107 & 2426 & 0.97 & 0.9209 & 1.0455 & 2509 \\
\hline 0.99 & 0.9748 & 1.0133 & 2432 & 0.965 & 0.8323 & 1.136 & 2726 \\
\hline 0.985 & 0.9658 & 1.0170 & 2441 & 0.9648 & 0 & - & - \\
\hline 0.98 . & 0.9552 & 1.0222 & 2453 & & & & \\
\hline
\end{tabular}

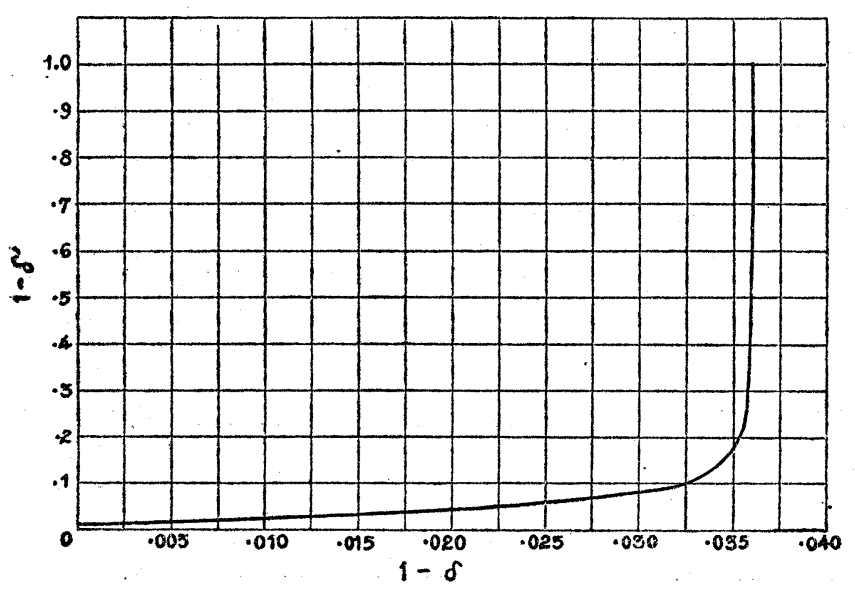

第 2 圆
一定溫度に保つたときのく びれの溫度 $\tau^{\prime}$ 及趩の溫度 $T^{\prime \prime}$ を計算すると第 3 表第 3 列及 第4列に示したやうになり， 蒸發の溫度指數に $n_{M}$ 艺用ひ て蒸發を簡單にて $n_{M}$ としたこ との影響は極めて僅かである ことがうなづける。

第 2 圖は橫軸に 1 - o り，縱軸に1ー方をこつたを ので，第 3 圖珄一定溫度に於

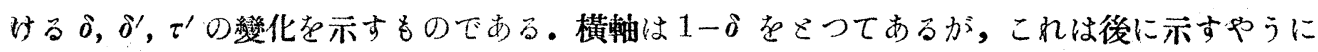
時間に比例する。 


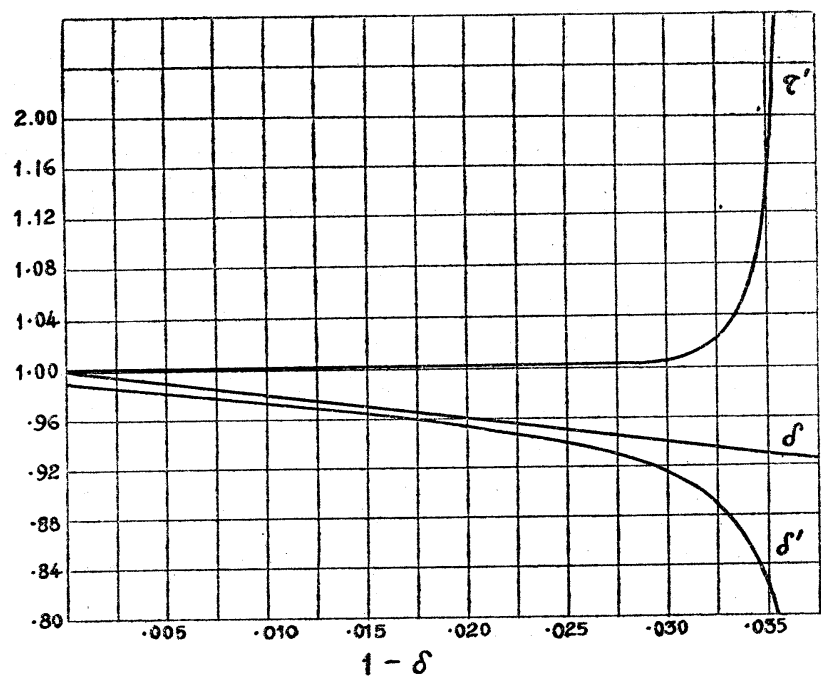

第 3 阔

\section{4. 固 有 動 程}

\section{1 固有動程の一般式}

特性には既に假定したやうにくびれた部分の特性が影響しないものとすれば，固有動程（長 さ $1 \mathrm{~cm}$ 直徑 $1 \mathrm{~cm}$ の瀻條の動程）は（2.1）式によつて

$$
t^{\prime}=\int_{\delta}^{1} \frac{\pi}{2} \frac{w}{M^{\prime}} d \delta
$$

厄゙すつて，假定によつて

$$
\begin{aligned}
& \frac{M^{\prime}}{M_{0}^{\prime}}=\tau^{n_{M}} \\
& \delta=\tau^{n_{D}} \ldots
\end{aligned}
$$

とおけば (4.1) 式は

$$
t^{\prime}=\frac{\pi}{2} \frac{w}{M_{0}^{\prime}} \cdot \frac{n_{D}}{n_{M}-n_{D}}\left[\tau^{n_{D}-n_{M}}-1\right]
$$

となる・(4.4) 式在き值すと

$$
t^{\prime}=\frac{\pi}{2} w \cdot \frac{n_{D}}{n_{M}-n_{D}}\left[\frac{\delta}{M^{\prime}}-\frac{1}{M_{0}^{\prime}}\right]
$$

となる。或は

$$
p=\frac{n_{M}}{n_{D}}-1 \text {. }
$$

とおけば

$$
t^{\prime}=\frac{\tau}{2} \frac{w}{M_{0}^{\prime}} \cdot \frac{1}{p}\left[\delta^{-p}-1\right]
$$


とをなる。

一定溫度に保つ場合には $M^{\prime}$ は一定であるから簡單に

$$
t^{\prime}=\frac{\pi}{2} \frac{w}{M_{\theta}^{\prime}}(1-\delta)
$$

である。

前節に还べたやうにくびれが同じ同一種の繊條をはじめの溫度を等しく或る特性を一定にす るやうに點火すれば，その特性の何れなるを問はず，くびれてるない部分の直徑るとくびれて

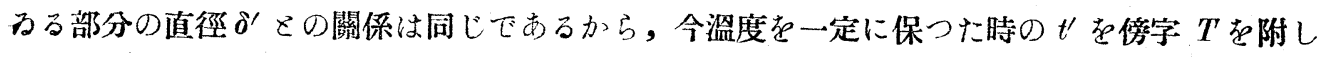
でとしてあらはすを

$$
\frac{t^{\prime}}{t^{\prime} T}=\frac{1}{1-\delta}, \frac{1}{p}\left(\delta^{-p}-1\right)
$$

であらはされ， $\delta$ が に近く

$$
\delta=1-\Delta
$$

とし, (4. 7) 式を展開すると

$$
\frac{t^{\prime}}{t^{\prime} T}=1+\frac{p+1}{2} \Delta+\frac{(p+1)(p+2)}{31} \Delta^{2}+
$$

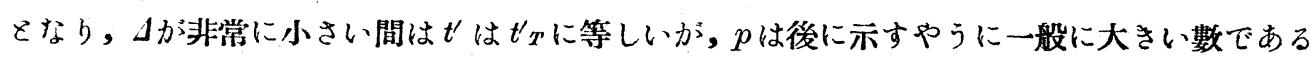

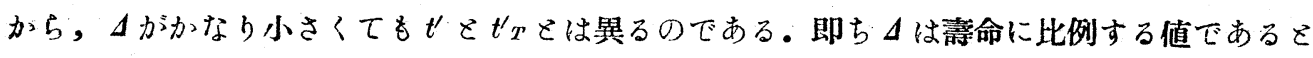
は一定溫度のとき以外は云へない。

\section{2 直徑の溫度特性}

固有特性の溫度指數を次に記す。

固有輻射束 $W^{\prime}: n_{W}$, 固有抵抗 ${ }^{(6)} R^{\prime}: n_{R}$, 固有電 流 $A^{\prime}: n_{A}$

固有電壓 $V^{\prime}: n_{V}$, 固有光束 $L^{\prime}: n_{L}$,

また始めの溫度に於ける固有特性の値はそれぞれ傍字。老附してあらはす。

さうすると

$$
\frac{W^{\prime}}{W_{0}^{\prime}}=\tau^{n_{W}} \text { 等 }
$$

であらはされる。 $n_{W}, n_{R}$ を用ひて他の指數をあらはすを

$$
\begin{aligned}
& n_{A}=\frac{n_{W}-n_{R}}{2} \\
& n_{V}=\frac{n_{M}+n_{R}}{2}
\end{aligned}
$$

である。

長さが一定であるとき，細まつてるる繊條の特性の變化は次の如し.

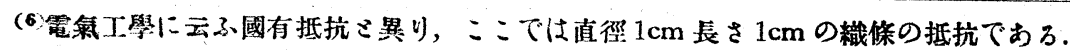




$$
\begin{aligned}
& \frac{W^{\prime} \delta}{W_{0}^{\prime}}=\tau^{n_{W}+n_{D}} \\
& \frac{R^{\prime}}{R_{0}^{\prime} \delta^{2}}=\pi^{n_{R}-2 n_{D}} \\
& \frac{A^{\prime} \delta^{\frac{3}{2}}}{A_{0}^{\prime}}=\tau^{n_{\mathrm{A}}+\frac{3}{2} n_{D}}=\pi \frac{n_{W}-n_{R}}{2}+\frac{3}{2} n_{D} \\
& \frac{V^{\prime}}{V_{0}^{\prime} \delta_{2}^{\frac{1}{2}}}=\tau \tau^{n_{V}}-\frac{1}{2} n_{D}=\tau \frac{n_{W}+n_{R}}{2}-\frac{1}{2} n_{D} \\
& \frac{L / \delta}{L_{0}^{\prime}}=\tau^{n_{L}+n_{D}}
\end{aligned}
$$

である。

能率は耭條の寸法には無關係で，能率 $c$ をであらはすと

$$
\frac{e^{\prime}}{e}=\tau^{n_{L}-n_{W}}
$$

\begin{tabular}{|c|c|c|c|c|c|}
\hline 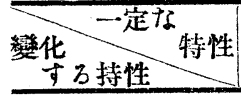 & $W$ & $R$ & $A$ & $V$ & $L$ \\
\hline$\delta$ & $-n_{W}$ & $\begin{array}{c}n_{R} \\
2\end{array}$ & $-\frac{n_{W}-n_{R}}{3}$ & $n_{W}+n_{R}$ & $-n_{L}$ \\
\hline$W$ & 0 & $\frac{2 n_{W}+n_{R}}{2}$ & $\frac{2 n_{W}+n_{R}}{3}$ & $2 n_{W}+n_{K}$ & $-\left(n_{L}-n_{W}\right)$ \\
\hline$R$ & $2 n_{W}+n_{R}$ & 0 & $\frac{2 n_{W}+n_{R}}{3}$ & $-\left(2 n_{W}+n_{R}\right)$ & $2 n_{X}+n_{R}$ \\
\hline$A$ & $-\frac{2 n_{W}+n_{R}}{2}$ & $\frac{2 n_{W}+n_{R}}{4}$ & 0 & $2 n_{W}+n_{R}$ & $-\frac{3 n_{L}-n_{W}+n_{R}}{2}$ \\
\hline$V$ & $\frac{2 n_{W}+n_{R}}{2}$ & $\frac{2 n_{W}+n_{R}}{4}$ & $\frac{2 n_{W}+n_{R}}{3}$ & 0 & $\frac{n_{L}+n_{W}+n_{R}}{2}$ \\
\hline$L$ & $n_{L}-n_{W}$ & $\frac{2 n_{L}+n_{R}}{2}$ & $\frac{3 n_{L}-n_{W}+n_{R}}{3}$ & $n_{L}+n_{W}+n_{R}$ & 0 \\
\hline
\end{tabular}

である・

或る特性ふふ一定なるとさ他の特性の溫度指數は第 4 表のやうになる。

第 4 表 或特性が一定なるときの他の特性の溫度指數

蒸發 $M$ は第 2 表に於て $n_{L}$ の代りに $n_{M}$ をおいたものである。

\section{4. $3 p$ の 值}

$p$ の値は (4. 5) 式によつて與へられ，第2 表の $n_{D}$ の値を入れると狄のやうになる。一策 とした特性を傍字として示す。

$$
\begin{array}{r}
p_{W}=-\left(\frac{n_{M}}{n_{W}}+1\right) ; p_{W}+1=-\frac{n_{M}}{n_{W}} \ldots \ldots \\
p_{R}=\frac{2 n_{M}}{n_{R}}-1 ; p_{R}+1=\frac{2 n_{M}}{n_{R}} \ldots . . \\
-16-
\end{array}
$$




$$
\begin{aligned}
& p_{A}=-\left(\frac{3 n_{M}}{n_{W}-n_{R}}+1\right) ; p_{A}+1=-\frac{3 n_{M}}{n_{W}+n} \\
& p_{V}=\frac{n_{M}}{n_{W}+n_{R}}-1 ; \quad p_{V}+1=\frac{n_{M}}{n_{W}+n_{R}} \\
& p_{L}=-\left(\frac{n_{M}}{n_{L}}+1\right) \quad ; \quad p_{L}+1=\frac{n_{M}}{n_{L}} \ldots . \\
& p_{T}=-1 ; p_{T}+1=0 \ldots \ldots \ldots \ldots \ldots \ldots \ldots
\end{aligned}
$$$$
T_{0}=2400^{\circ} K \text { のきの } p \text { の値を示せば第 } 5 \text { 表の如し・ }
$$

\begin{tabular}{|c|c|c|c|c|c|c|c|}
\hline & $2300^{\circ} \mathrm{K}$ & $2400^{\circ} K$ & $2500^{\circ} \mathrm{K}$ & & $2300^{\circ} K$ & $2400^{\circ} K$ & $2500^{\circ} K$ \\
\hline$p_{R}$ & 67.35 & 64.24 & 61.35 & $p_{L}$ & -4.765 & -4.752 & -4.736 \\
\hline$p_{V}$ & 5.861 & 5.616 & 5.380 & $p_{W}$ & -9.584 & -9.299 & -9.024 \\
\hline$p T$ & -1 & -1 & -1 & $p_{A}$ & -35.39 & -34.39 & -33.42 \\
\hline
\end{tabular}

\section{4 一定なる特性に於ける動程の比較}

或る特性を一定としたときの動程の比較は（4．7）又は（4．9）式によつて出來る。

等しい $\delta$ となるだの時間は $t^{\prime}$ であるが，特性 $X$ を一定とするそきの $t^{\prime}$ を $t^{\prime} x$ そしてらら はすと，(4.9) 式によつて

$$
\frac{t^{\prime}{ }_{x}}{t^{\prime}{ }_{T}}=1+\frac{p_{\boldsymbol{X}}+1}{2} \Delta+\ldots \ldots \ldots \ldots \ldots
$$

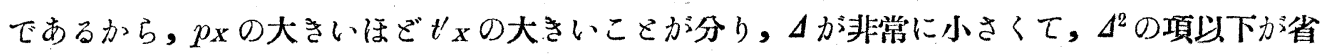
略されるときには $t^{\prime} \boldsymbol{x} / t^{\prime}$ は $1+\frac{p_{X}+1}{2} \Delta と な る$ 從つて

$$
t^{\prime}>t^{\prime}{ }_{V}>t^{\prime}{ }_{T}>t^{\prime}{ }_{L}>t^{\prime}{ }_{W}>t^{\prime}{ }_{A}
$$

である．即ち最す緩く變化するのは抵抗を一定にしたときで，電壓を一定にしたときはこれに 次ぎ，上下能率一定，光束一定，入力一定の順になり，電流一定の場合最も短い。

\section{5 數 字 例}

$\delta_{0}{ }^{\prime}=0.99, T_{0}=2400^{\circ} \mathrm{K} に 一$ 定に保つた場合の $t^{\prime}$ 及 $D_{0}=30 \mu$ 及 $45 \mu$ のときの時間を示すと， 第 6 表の値となる。

第 6 表 $\quad \delta_{0}^{\prime}=0.99, \quad T_{0}=2400^{\circ} \mathrm{K}$

\begin{tabular}{c|c|c|c}
\hline \multirow{2}{*}{$\delta$} & $t$ (時) & $D_{0}=30 \mu$ & $t$ (時) \\
\cline { 2 - 3 } & & 0 & $D_{0}=45 \mu$ \\
\hline 1.00 & 0 & 192 & 0 \\
0.99 & $6.41 \times 10^{4}$ & 384 & 298 \\
0.98 & $1.28 \times 10^{5}$ & 577 & 577 \\
0.97 & $1.92 \times 10^{5}$ & 676 & 961 \\
0.965 & $2.25 \times 10^{5}$ & & 1014
\end{tabular}


この瀻條を $T_{0}=2400^{\circ} \mathrm{K}$ になる或る特性を一定に保つとき, $t_{0}{ }^{\prime} x / t_{0}{ }^{\prime} T$ は第 7 表第 4 圖のやう になる。

第 7 表 $\quad \frac{t_{0}{ }^{\prime} x}{t_{0}{ }^{\prime} \mathrm{T}}$ の値, $\delta_{0}{ }^{\prime}=0.99, T_{0}=2400^{\circ} \mathrm{K}$

\begin{tabular}{l|l|l|l|l|l}
\hline \multicolumn{1}{c|}{$\delta$} & $R$ - 定 & $V$ - 定 & $L-$ 定 & $W$ - 定 & $A$ - 定 \\
\hline 0.995 & 1.183 & 1.017 & 0.991 & 0.979 & 0.921 \\
0.99 & 1.412 & 1.034 & 0.981 & 0.960 & 0.850 \\
0.985 & 1.702 & 1.052 & 0.972 & 0.940 & 0.786 \\
0.98 & 2.071 & 1.070 & 0.963 & 0.921 & 0.728 \\
0.975 & 2.544 & 1.088 & 0.954 & 0.902 & 0.676 \\
0.97 & 3.153 & 1.107 & 0.945 & 0.886 & 0.629 \\
0.965 & 3.941 & 1.127 & 0.936 & 0.866 & 0.587
\end{tabular}

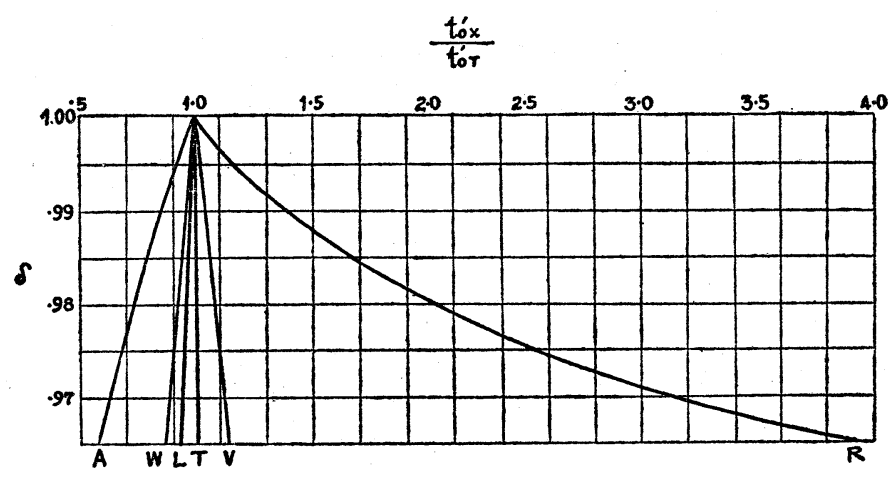

第 4 圖

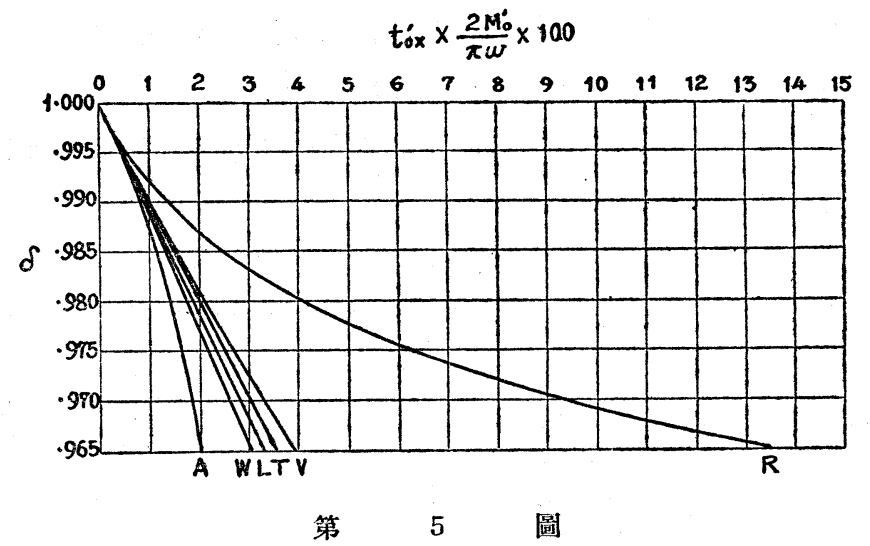

第 5 圖は橫軸に時間をとり，縱軸に $\delta$ をつて示したものである。 


\section{5. 燒 斷 壽 命}

\section{1 燒斷壽命の一般式}

前に述べて來た所によつて，固有壽命は求められるが，最初のくびれ $\delta_{0}^{\prime}$ が等しい場合には 溫度によつて燒斷時の細まり $\delta_{0}$ が求められ

$$
\delta_{0}=\tau_{0}^{n_{D}}
$$

によつてその時の溫度 $\tau_{0}$ が求められる。

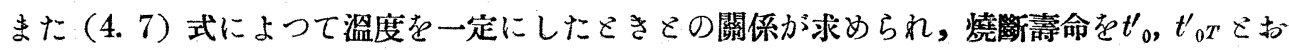
けば

$$
\frac{t_{0}^{\prime}}{t_{0}{ }^{\prime} \boldsymbol{T}}=\frac{1}{1-\delta_{0}} \frac{1}{p}\left(\delta_{0}-p-1\right)
$$

によつて興へられることも全く同じ，從つて $\delta_{0}$ が 1 に近いものでは (4.9) 式と全く同じもの であらはされる。

$$
\begin{aligned}
& t_{0}{ }^{T} \text { は云ふまでもなく } \\
& \qquad t_{0}{ }^{\prime}=\frac{\pi}{2} \frac{w}{M_{0}{ }^{\prime}}\left(1-\delta_{0}\right)
\end{aligned}
$$

である。

\section{2 壽 命の 比 較}

（a）同一の繊條を或特性が一定となるやうしたときの壽命は（5．2）式で比較せられ，前

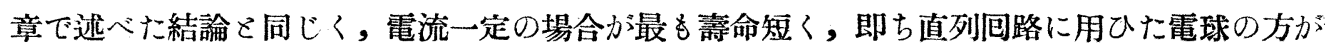
並列问路に用ひた電球よりも言命が短い.

$\delta_{0}{ }^{\prime}=0.99, T_{0}=2400^{\circ} \mathrm{K}$ に於て比較すれば第 8 表のやうになる． $D_{0}=30 \mu, 45 \mu$ のときの壽 命をも附記しておく.

第 8 表 一定な特性と壽命

$$
\delta_{0}{ }^{\prime}=0,89, \quad T_{0}=2400^{\circ} \mathrm{K}
$$

\begin{tabular}{c|c|c|c|c}
\hline \multirow{2}{*}{ 一定な特牲 } & $t_{0}^{\prime} / t_{0}{ }^{\prime} T$ & $t_{0}^{\prime}$ (時) & \multicolumn{2}{|c}{ 壽 命 (時) } \\
\cline { 3 - 4 } & & & $D_{0}=30 \mu$ & $D_{0}=45 \mu$ \\
\hline$R$ & 3.973 & $8.952 \times 10^{5}$ & 2686 & 4028 \\
$V$ & 1.128 & $2.540 \times 10^{5}$ & 762 & 1143 \\
$T$ & 1.000 & $2.253 \times 10^{5}$ & 676 & 1014 \\
$L$ & 0.936 & $2.109 \times 10^{5}$ & 633 & 949 \\
$W$ & 0.866 & $1.951 \times 10^{5}$ & 585 & 878 \\
$A$ & 0.586 & $1.319 \times 10^{5}$ & 396 & 594
\end{tabular}

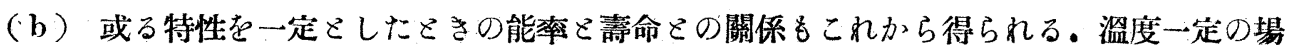


合には，壽命は $\left(1-\delta_{0}\right) / M_{0}^{\prime}$ に比例し，第 2 表に示すやうに $1-\delta_{0}$ は溫度によつてあまり大 きくかはらないから，壽命は殆んど $M_{0}^{\prime}$ に逆比例を見做してもよい位で，溫度指數は殆んど $M_{0}^{\prime}$ の溫度指數の符號を變じたものであるから, 能率の溫度指數との關係から, 壽命は初能率 のほメ゙ー7乘にかはることが求められる。

他の特性が一定の場合も亦同樣であつて，一定電壓に於る壽命指數を求めるを $2400^{\circ} \mathrm{K}$ に於 てほડ゙6.64であつて，溫度が高いほどこの値 は大きくなる

（c）織條の太さと壽命との關係は上に迡 ベて來たやうに，繊條のくびれがー定なら ば，同一溫度に於ては初めの直徑に比例する のであるが，一般には太いほど長くなつてる る. Koref 及 Plaut 兩氏の云つてるるやう にくびれの程度の絕對値が繊條の太さにほず 無關係であるとすれば, $1-\delta_{0}^{\prime}$ は繊條の太さ に逆比例して小さくなる．云ひかへると，織 條の太さが大きいほど $\delta_{0}^{\prime}$ が大きく從つて $\delta_{0}$ が小さい，即ち唚命が直徑に比例するよりは 長い。

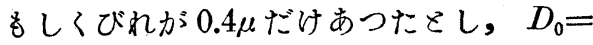
$15 \mu, 20 \mu, 30 \mu, 40,50 \mu$, の場合, $T_{0}=2400^{\circ} \mathrm{K}$ とし，溫度一定の場合を比較すれば，第 9 表 の如し. 第 6 圖は $D_{0}$ に對する壽命を示す。

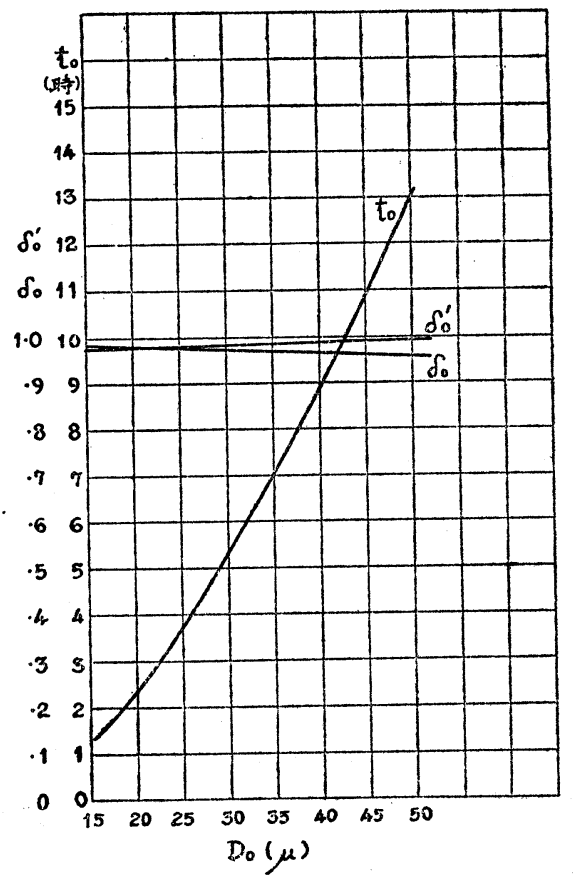

第 6 圖

第 9 表 $\quad \delta_{0}^{\prime}=1-\frac{0.4}{D_{0}(\mu)}, \quad T_{0}=2400^{\circ} \mathrm{K}$

\begin{tabular}{c|l|l|l|l|l}
\hline$D_{0}(\mu)$ & \multicolumn{1}{|c|}{15} & \multicolumn{1}{c|}{20} & \multicolumn{1}{c|}{30} & \multicolumn{1}{c}{40} & \multicolumn{1}{c}{50} \\
\hline$\delta_{0}{ }^{\prime}$ & 0.9733 & 0.98 & 0.9867 & 0.99 & 0.992 \\
$\delta_{0}$ & 0.9855 & 0.9801 & 0.9715 & 0.9648 & 0.9595 \\
$1-\delta_{0}$ & 0.0145 & 0.0199 & 0.0285 & 0.0352 & 0.0405 \\
$t_{0}{ }^{\prime}$ (時) & $9.29 \times 10^{4}$ & $1.28 \times 10^{5}$ & $1.83 \times 10^{5}$ & $2.25 \times 10^{5}$ & $2.60 \times 10^{5}$ \\
$t_{0}$ (時) & 139 & 256 & 549 & 900 & 1300
\end{tabular}

\section{6. 各特性の動程}

6. 1 動程の一般式

第 4 章に述べた所により，時間と直徑の細まりとの關係が得られ，第 2 表に示した指數を用 
れば，各瞬時に於ける諸特性の變化が算出されることは云ふまでるない。

溫度をてとすれば

$$
\delta=\tau^{n_{D}}
$$

であるから，第 2 表に示した特性 $X$ の溫度指數を $n^{\prime} \boldsymbol{x}$ をすれば特性の變化は

$$
\frac{X}{X_{0}}=\tau^{n^{\prime} x}=\delta^{\frac{n_{X}^{\prime}}{n_{D}}}
$$

によつて興へられる。

\section{2 動程の比較}

電球の使用目的に從つて各種特性の一樣さの比較を必要とする場合が度々あらう. 以下 2,3 の例について示すこととする。

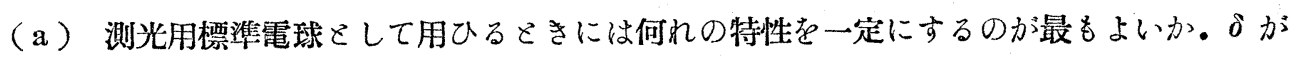
1 に非常に近い場合には何れの特性を一定にしてもほづ同時間に同樣に細まつてるるから， (6. 2) 式に於て $n_{L}^{\prime} / n_{D}$ の値が最も小さい場合がよいことになる。

$$
\frac{n_{L}^{\prime}}{n_{D}}=\frac{n_{L}+n_{D}}{n_{D}}=\frac{n_{L}}{n_{D}}+1
$$

であるから，光束一定の場合を除さ入力一定の場合最もよく，電壓一定の場合之につぎ，電流 一定の場合は更に惡く，抵抗一定の場合最も惡い.溫度一定の場合は光束は $\delta$ に比例し，普通 の溫度に於ては入力一定の場合よりはよいが， $2800^{\circ} \mathrm{K}$ 以上に於ては入力一定の場合に劣る。

(b) 光高溫計用電球又は光色測定用電球のやうに絨條溫度を成るべく一定にするには $\delta^{1 / n_{D}}$. が 1 に近いほどよく, 從つて $n_{D}$ の絕對値の大きい方がよい. 溫度一定, 光束一定の場合を除 き電壓一定の場合最もよく, 入力一定之に次ぎ, 電流一定, 抵抗一定の順である。

（c）壽命中の發散光量の比較は次の如し. 發散光量を $Q$ とすれば

$$
Q=\int_{0}^{t_{0}^{\prime}} \tau^{n_{L}+n_{D}} d t^{\prime}
$$

であるから，

$$
\begin{aligned}
Q & =\int_{\delta_{0}}^{1} \tau n_{L}+n_{D} \cdot \frac{d \delta}{M^{\prime}} \cdot \frac{\pi w}{2} \cdots \cdots \cdots \\
& =\frac{\pi w}{2 M_{0}^{\prime}} \cdot \frac{n_{D}}{n_{L}+2 n_{D}-\mathrm{n}_{M}}\left[1-\tau_{0}^{n_{L}+2 n_{D}-n_{M}}\right] \ldots \\
& =\frac{t_{0}{ }^{\prime} T}{1-\delta_{0}} \cdot \frac{n_{D}}{n_{M}-2 n_{D}-n_{L}}\left[\delta_{0}^{\left.\frac{n_{L}+2 n_{D}-n_{M}}{n_{D}}-1\right]}\right.
\end{aligned}
$$

今 $q$ を次のやうにおく。

$$
q=\frac{n_{M}-2 n_{D}-n_{L}}{n_{D}}=\frac{n_{M}-n_{L}}{n_{D}}-2
$$

さうすると光量は 


$$
Q=\frac{t_{0}^{\prime} T}{1-\delta_{0}} \cdot \frac{1}{q}\left[\delta_{0}^{-q}-1\right]
$$

そなり（5.2) 式と同型となつて $\delta_{0}$ が 1 に近ければ

$$
Q=t_{0}{ }^{\prime} \Delta_{0}\left(1+\frac{q+1}{2} \Delta_{0}+\cdots \cdots \cdots\right) \text {. }
$$

そなり，qの大なるほど，從つて $n_{D}$ の小なるほど大となる．この點から云へば抵抗一定の場 合最も大で，

$$
Q_{R}>Q_{V}>Q_{T^{\prime}}>Q_{L}>Q_{W}>Q_{A}
$$

の順となる。

\section{（d）壽命中本均特性}

壽命中の本均能率は如何程となるか等, 壽命中の本均特性を知る要があることがある。これ は光量を求めたのと同樣な方法によつて決定される。

$$
\text { 結 び }
$$

以上述べた所によつて次の結墖を得。

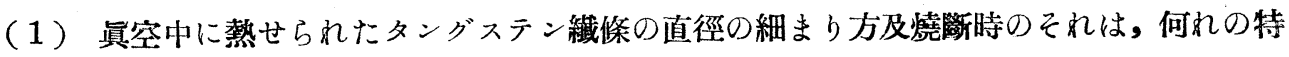
性を一定とするる溫度站にくびれの直徑によつて定まり，燒斷壽命は更に初めのくびれない部 分の直徑に比例する。

（2）一定とする特性によつて壽命は著しく異る。

（3）初めの直徑及くびれの直徑を與へ，ある特性を一定としたときの他の特性の動程を決 定することが出來る。

本論は簡單な假定のもとに全く理論的に運んだもので，假定の吟味は行はなかつた。本論は 更にコイル瀻條の場合，ガス入電球の場合，また㵶條に沿ふ溫度分布を考に入れた場合等に擴 充されなければならない（昭和11年 8 月） 